\title{
Karakter Gotong Royong dalam Paket Pembelajaran Tokoh Sema
}

\author{
Elina Sitompul ${ }^{1 凶}$, Nurbiana Dhieni $^{1}$, Hapidin $^{1}$ \\ Pendidikan Anak Usia Dini, Universitas Negeri Jakarta, Indonesia(1) \\ DOI: $10.31004 /$ obsesi.v6i4.1674
}

\begin{abstract}
Abstrak
Gotong royong merupakan salah satu nilai karakter kebangsaan Indonesia yang melekat dalam kehidupan masyarakat. Meski demikian, saat ini banyak anak usia dini tumbuh dengan suasana individual. Penelitian dilakukan untuk mendesain paket pembelajaran tokoh "Sema (Semut Merah)" sebagai sarana penanaman karakter gotong royong anak usia 4-6 tahun. Studi ini menggunakan metode kualitatif dengan teknik analisis Miles Huberman. Paket pembelajaran tokoh Sema terdiri dari materi pembelajaran, buku cerita, lagu, video pembelajaran, asesmen dan aktivitas bersama orang tua. Paket pembelajaran menerjemahkan karakter gotong royong yang abstrak menjadi perilaku konkrit berdasarkan kisah keteladanan tokoh Sema yang menginspirasi. Berdasarkan temuan penelitian disimpulkan proses implementasi memiliki pola: 1) penyamaan persepsi pendidik, 2) pengembangan program sesuai ciri dan karakterisik satuan PAUD, 3) praktik mengajar mandiri, 4) membangun komunikasi efektif dengan orang tua mengenai nilai karakter, 5) proses implementasi dan asesmen, serta 6) pemberian umpan balik oleh peserta didik dan orang tua.
\end{abstract}

Kata Kunci: paket pembelajaran; karakter; gotong royong.

\begin{abstract}
Mutual cooperation is one of the values of Indonesian national character that is inherent in people's lives. However, nowadays many young children grow up with an individual atmosphere. The research was conducted to design a learning package for the character "Sema (Semut Merah)" as a means of inculcating the character of mutual cooperation for children aged 4-6 years. This study uses a qualitative method with Miles Huberman's analytical technique, where the participants are 45 children and 5 teachers at the Jakarta Methodist Kindergarten. The Sema character learning package consists of learning materials, story books, songs, learning videos, assessments and activities with parents. The learning package translates abstract gotong royong characters into concrete behavior based on the inspiring story of Sema's role model. Based on the research findings, it is concluded that the implementation process has a pattern: 1) equalizing perceptions of educators, 2) developing programs according to the characteristics and characteristics of PAUD units, 3) independent teaching practices, 4) building effective communication with parents regarding character values, 5) implementation and assessment processes, and 6) providing feedback by students and parents
\end{abstract}

Keywords: learning package; character; mutual cooperation.

Copyright (c) 2022 Elina Sitompul, et al.

$\triangle$ Corresponding author :

Email Address : ElinaSitompul_9909819006@mhs.unj.ac.id (Jakarta, Indonesia)

Received 22 July 2021, Accepted 19 August 2022, Published 27 February 2022

Jurnal Obsesi : Jurnal Pendidikan Anak Usia Dini, 6(4), 2022 | 3473 


\section{PENDAHULUAN}

Karakter kebangsaan adalah suatu tatanan nilai dan keyakinan yang mendasari kebudayaan masyarakat serta mencerminkan kepribadian masyarakat itu sendiri. Membangun karakter kebangsaan adalah upaya untuk menjaga keberagaman dan melestarikan cara hidup masyarakat sesuai dengan falsafah bangsa Indonesia. Karakter kebangsaan menjadi dasar perilaku moral kehidupan bermasyarakat yang bertanggung jawab, saling peduli, tolong menolong dan berkontribusi bagi kepentingan orang banyak (Isfihani, 2017). Adapun salah satu nilai karakter kebangsaan yang menjadi dasar kehidupan bermasyarakat Indonesia adalah gotong royong.

Gotong royong merupakan suatu istilah dalam Bahasa Indonesia yang menggambarkan proses bekerja bersama-sama untuk mencapai suatu hasil yang diinginkan. Gotong royong membutuhkan partisipasi dan keterlibatan aktif setiap anggota untuk bekerja sama memberi dampak positif terhadap suatu permasalahan atau kebutuhan yang dihadapi (Unayah, 2017). Namun, belakangan ini terjadi perubahan sosial yang menunjukkan nilai gotong royong semakin melemah dan berkembang relasi sosial yang bersifat individualis, materialistik dan mengutamakan kebebasan (Effendi, 2016). Padahal, gotong royong merupakan modal sosial dalam menghadapi berbagai tantangan bersama dan memenuhi kebutuhan masyarakat saat ini (Unayah, 2017).

Karakter gotong royong penting ditanamkan pada anak sejak dini agar mampu bekerja dengan orang lain, membangun relasi dalam tim dan bekerja sama mencapai tujuan tertentu (Rich, 2008). Sikap mau bekerjasama menunjukkan relasi saling memberi dan menerima, guna mencapai suatu tujuan yang sama (Santrock, 2017). Perilaku kerja sama dan bergotong royong membantu anak mampu membangun hubungan pertemanan, sikap prososial dan respon positif dalam mengendalikan emosi (Kostelnik et al., 2012). Oleh karena itu, penting bagi satuan pendidikan berperan strategis untuk menanamkan karakter royong mulai dari lingkungan satuan pendidikan anak usia dini. Dengan penanaman gotong royong sejak dini, anak belajar untuk membangun relasi positif, berpartisipasi aktif dalam penyelesaian masalah, memberi kontribusi dalam kelompok serta saling tolong menolong.

Karakter kebangsaan gotong royong pada konteks anak usia dini mencakup sikap peduli, bekerja sama, demokrasi, pembiasaan musyawarah mufakat, diskusi, tolong menolong, sikap solidaritas, empati, anti diskriminasi, setia kawan dan kerelawanan (Direktorat Pembinaan Pendidikan Anak Usia Dini, 2019). Menanamkan rasa kebersamaan pada anak usia dini untuk gotong royong bukanlah hal yang mudah. Gotong royong dibangun melalui hubungan pertemanan, pembiasaan perilaku prososial dan sikap positif dalam mengendalikan emosional (Kostelnik et al., 2012). Adapun beberapa upaya yang dapat dilakukan pendidik untuk menanamkan sikap gotong royong pada anak usia dini melalui: 1) pemberian pemahaman prinsip gotong royong, pembagian tugas dan kerjasama melalui berbagai media; 2) pengembangan aktivitas proyek kelompok; dan 3) pembiasaan diskusi untuk Menyusun perencanaan dan penyelesaian tugas bersama (Rich, 2008).

Mengenalkan karakter kebangsaan pada anak perlu didukung berbagai sumber dan desain pembelajaran yang sesuai dengan karakteristik anak. Namun, kenyataannya tantangan implementasi pendidikan karakter dalam proses pembelajaran merupakan akibat kurangnya pemahaman guru mengenai nilai karakter yang diajarkan, keterbatasan desain pembelajaran dan pemilihan pendekatan yang sesuai (Shubert et al., 2019). Perlu adanya program karakter yang terencana dan komprehensif merupakan langkah awal dan upaya terus menerus agar suatu nilai karakter dapat terintegrasi dengan semua aspek kehidupan sekolah (Lickona et al., 2011). Penanaman karakter, misalnya gotong royong, hendaknya menjadi komitmen bersama semua pihak yang dirancang dan diupayakan secara sistematis untuk membantu anak memahami makna nilai kebangsaan dan perilakunya dalam kehidupan sehari-hari (Trimuliana et al., 2019). 
Permasalahan di atas menjadi dasar pemikiran untuk mengembangkan desain paket pembelajaran sebagai suatu program khusus yang menanamkan nilai gotong-royong pada anak usia 4-6 tahun. Salah satu upaya penyediaan sumber belajar karakter adalah dengan mendesain paket pembelajaran. Paket pembelajaran adalah kombinasi multi media yang berisi tujuan, capaian, konten, aktivitas pengalaman belajar serta alat pendukung yang dapat digunakan anak secara berkesinambungan (Sawangsri, 2016). Salah satu bentuk rekayasa pembelajaran yang memanfaatkan beberapa sumber belajar guna pelaksanaan pembelajaran yang lebih efektif, efisien dan berdaya tarik tinggi disebut dengan paket pembelajaran (Akbar et al., 2019). Paket pembelajaran dapat mencakup panduan berbasis bukti, alat peraga pendukung, dan ragam sumber belajar (Blake H et al., 2020).

Desain paket pembelajaran mempertimbangkan beberapa aspek, diantaranya konten atau materi, alat peraga, strategi, pendekatan peserta didik, metode pembelajaran serta ketersediaan sumber belajar (Murtafiah, Inaya Masrura, et al., 2018). Pada umumnya, cakupan paket pembelajaran jenjang PAUD berupa materi pembelajaran, alat peraga dan media yang mengacu pada konsep pengetahuan dan keterampilan hidup anak (Djufri \& Suardi, 2012). Paket pembelajaran pada jenjang anak usia dini digunakan untuk menyampaikan pesan, meningkatkan kesadaran peserta didik, orang tua dan guru mengenai suatu permasalahan, serta memberi panduan lengkap tentang suatu topik melalui rangkaian seminar, buku panduan guru, poster, media pembelajaran, instrumen pengamatan, aktivitas bermain serta alat peraga (Al-Delaimy et al., 2014). Oleh karena itu, untuk menanamkan karakter kebangsaan gotong royong diperlukan sebuah desain paket pembelajaran yang sesuai dengan karakterisik anak usia 4-6 tahun.

Penelitian ini bertujuan mendeskripsikan desain paket pembelajaran tokoh inspiratif yang dinamai "Sema" (Semut Merah) sebagai sarana penanaman karakter gotong royong anak usia 4-6 tahun. Tokoh inspiratif adalah sosok figur yang memberi motivasi, dorongan, keteladanan dan sumber inspirasi yang berpegang pada keyakinan nilai tertentu (OcampoGooding, 2018). Tokoh inspiratif merupakan pemodelan yang secara psikis menginspirasi orang lain melalui tindakan, cara berkomunikasi, nilai dan visi serta memberi pengaruh positif terhadap situasi dan lingkungan sekitar (Searle \& Hanrahan, 2011). Keberadaan tokoh inspiratif dapat jadi model perawakan yang memberi motivasi dan keteladanan mengenai suatu nilai karakter.

Tokoh Sema memiliki cara hidup dan perilaku yang merepresentasi dan menginspirasi karakter gotong royong. Berbagai penelitian menemukan bahwa semut adalah serangga yang paling cerdas, paling terorganisir, pekerja paling keras, paling kooperatif dan sangat komunikatif (Gordon, 2010). Semut adalah binatang yang hidup berkoloni dan memiliki struktur sosial yang saling bekerjasama (Lach et al., 2010). Satu koloni umumnya terdiri dari 100.000 - 500.000 anggota semut yang paling sedikit dipimpin seekor semut ratu. Semut merupakan binatang sosial yang hidup lintas generasi dalam satu koloni dengan pembagian tugas yang terorganisasi (Choe, 2012). Meski berukuran kecil, semut termasuk binatang terkuat di dunia karena mampu menopang beban yang memiliki berat lima puluh kali lebih berat dibanding dirinya sendiri.

Koloni semut merupakan binatang dengan struktur sosial yang sangat terorganisir, dimana setiap anggota memiliki tugas dan tanggung jawab masing-masing (Lach et al., 2010). Pembagian tugas koloni semut diantaranya: a) semut ratu (menghasilkan telur kurang lebih 1.500 telur/hari); b) semut muda (mengantarkan telur semut ke 'kamar' penyimpanan dan memberi makan larva yang baru menetas); c) semut jantan (memelihara gundukan sarang, menjaga kebersihan terowongan dan menggali sarang baru saat koloni berkembang, membuahi semut ratu); d) semut pekerja yang lebih tua (mencari makanan di luar sarang) dan e) semut tentara atau penjaga (melindungi gundukan sarang dari makhluk apapun yang mencoba masuk (Choe, 2012). Semut pekerja mengumpulkan daun, serbuk kayu dan lumpur yang ukurannya lebih besar dari tubuhnya untuk membuat sarang sedangkan semut tentara memiliki ukuran lebih kekar untuk mempertahankan sarang. 
Semut memiliki dua kantong perut yang memiliki fungsi berbeda. Satu perut digunakan untuk menyimpan konsumsinya sendiri, sementara satu kantong perut lainnya menyimpan makanan yang akan dibagikan kepada semut lainnya. Proses ini disebut trophallix dimana semut pekerja membagikan makanan kepada semut yang melayani ratu di sarang ataupun semut lain yang kelaparan. Ciri khusus semut adalah memiliki antena dan abdomen (Feldman \& Karapetkova, 2010). Abdomen digunakan untuk mengeluarkan bau feromon sebagai alat komunikasi atau meninggalkan jejak, sedangkan antena digunakan untuk saling menyapa, berkomunikasi dan memberi informasi makanan atau tanda bahaya.

Kajian mengenai cara hidup semut menunjukkan bahwa semut merupakan tokoh binatang yang mencerminkan karakter gotong royong. Hal ini ditunjukkan melalui cara hidup semut yang mengutamakan kepentingan koloni daripada kepentingan pribadi, saling berbagi, tertib bergiliran, komunikasi dan kerjasama dalam mencapai suatu tujuan. Dalam hidup berkoloni, semut memiliki struktur sosial dengan pembagian tugas yang terorganisir. Semut adalah binatang yang rajin, pekerja keras dan bertanggung jawab menyelesaikan tugasnya. Semut merupakan binatang yang kooperatif dan menjalin komunikasi, dimana dalam kehidupan bergotong royong, anak perlu mempelajari sikap-sikap tersebut.

Paket Pembelajaran Sema sebagai sarana penanaman karakter kebangsaan gotong royong merupakan produk yang belum pernah dikembangkan di Indonesia sebelumnya. Tokoh Sema dipilih karena memiliki cara hidup dan perilaku yang merepresentasi nilai gotong royong. Adapun pada penelitian ini, paket pembelajaran yang dikembangkan terdiri dari: materi pembelajaran sebagai panduan guru, aktivitas keterlibatan orang tua, asesmen dan media pembelajaran berupa: cerita bergambar tokoh Sema, lagu karakter, kalimat inspiratif dan kata fokus karakter gotong royong.

\section{METODOLOGI}

Sebelum proses implementasi, produk berupa Paket Pembelajaran Tokoh Sema dikembangkan melalui rangkaian proses ADDIE. Hasil pengembangan produk diimplementasi di satuan PAUD di wilayah DKI Jakarta yang ditentukan menggunakan teknik purposive sampling. Produk diimplementasikan selama dua minggu pada dua kelompok usia, yaitu: kelompok A (4-5 tahun) dan kelompok B (5-6 tahun) disemester genap tahun pelajaran 2020/2021. Data penelitian berupa catatan lapangan, catatan wawancara dan catatan dokumentasi diolah menggunakan metode kualitatif dengan teknik analisis Miles Huberman. Jadwal penelitian implementasi paket pembelajaran tokok Sema disajikan pada tabel 1.

Tabel 1. Jadwal Penelitian Implementasi Paket Pembelajaran Tokoh Sema

\begin{tabular}{|c|c|c|c|}
\hline No. & Tanggal & $\begin{array}{l}\text { Wakt1 } \\
\text { (WIB) }\end{array}$ & Kegiatan \\
\hline 1. & 11 Mei 21 & $\begin{array}{l}08.00 \\
09.00\end{array}$ & $\begin{array}{l}\text { Pertemuan antara peneliti dan Kepala Sekolah TK untuk penyampaian penjelasan } \\
\text { produk dan penyusunan agenda diskusi bersama pendidik terkait untuk proses } \\
\text { implementasi. }\end{array}$ \\
\hline 2. & 11 Juni 21 & $\begin{array}{l}13.00 \\
14.00\end{array}$ & $\begin{array}{l}\text { Koordinasi dan penjelasan prosedur penggunaan paket pembelajaran pada } \\
\text { pendidik. Pada tahapan ini peneliti dan pendidik melakukan diskusi alokasi } \\
\text { waktu implementasi, pengembangan aktivitas dan learning tools karakter } \\
\text { kebangsaan sesuai dengan karakteristik sekolah. } \\
\text { Jadwal harian yang disepakati adalah sebagai berikut: } \\
\text { 7.30-7.50: pembukaan, ayat Alkitab, lagu karakter, kalimat inspiratif, dan } \\
\text { pengenalan tokoh karakter } \\
\text { 7.50-8.05: ulasan penerapan karakter berdasarkan tokoh inspiratif (breakout room } \\
\text { A dan B) } \\
\text { 8.05-8.15: aktivitas pengembangan karakter menggunakan learning tools. }\end{array}$ \\
\hline 3. & $\begin{array}{l}21-25 \\
\text { Juni } 21\end{array}$ & $\begin{array}{l}07.30 \\
08.15\end{array}$ & $\begin{array}{l}\text { Pengenalan enam sub nilai karakter gotong royong, yaitu: berbagi tugas dengan } \\
\text { bekerja sama, tertib dalam bekerja, pekerja keras dan sungguh-sungguh, memiliki } \\
\text { sikap peduli, mau berkomunikasi dengan baik serta berdiskusi (musyawarah) } \\
\text { untuk menghasilkan keputusan bersama. }\end{array}$ \\
\hline
\end{tabular}




\section{Model Draf Paket Pembelajaran Tokoh Sema}

Tahap pengembangan produk dilakukan untuk melakukan perbaikan produk secara bertahap sesuai dengan masukan yang diterima peneliti. Proses perbaikan model produk draf 1 melibatkan penilaian dari dua orang pakar, yaitu Pakar PAUD dan Pakar Media Pembelajaran. Berdasarkan penilaian pakar, pada tabel 2 disajikan beberapa masukan yang diberikan untuk produk paket pembelajaran tokoh inspiratif sebagai sarana penanaman karakter kebangsaan anak usia 4-6 tahun.

\section{Tabel 2. Hasil Penilaian Uji Pakar}

\begin{tabular}{lll}
\hline Kriteria & Pakar PAUD & Pakar Media Pembelajaran \\
\hline Skor akhir & $72 / 80$ & $64 / 80$ \\
Kesimpulan & Layak dengan perbaikan & Layak dengan perbaikan \\
\hline
\end{tabular}

Berdasarkan hasil Uji Pakar PAUD dan Pakar Media Pembelajaran disimpulkan bahwa draf Paket Pembelajaran Tokoh Sema layak digunakan dengan beberapa perbaikan. Beberapa poin yang perlu diperbaiki diantaranya: a) perbaikan lirik lagu dan b) penjelasan tambahan mengenai alokasi waktu dan informasi pakaian adat yang dikenakan tokoh inspiratif dan c) penyederhanaan bahasa. Hasil perbaikan uji coba digunakan pada tahap berikutnya.

\section{HASIL DAN PEMBAHASAN}

Karakter kebangsaan gotong royong dapat dapat ditanamkan pada anak usia dini melalui desain paket pembelajaran. Pada jenjang SD-SMA, paket pembelajaran paling tidak berupa pedoman atau panduan pendidik, buku teks dan lembar pengamatan (Murtafiah, Inaya Masrura, et al., 2018). Pada konteks anak usia dini, paket pembelajaran dapat berbentuk rangkaian seminar pendidik, buku pedoman pendidik, diskusi orang tua, poster dan gambar, media pembelajaran, aktivitas bermain serta alat peraga (Al-Delaimy et al., 2014).

Tabel 3. Paket Pembelajaran Tokoh Sema

\begin{tabular}{|c|c|c|c|}
\hline Nama Tokoh & Ciri Fisik/cara Hidup Semut & $\begin{array}{l}\text { Sub Nilai Karakter } \\
\text { Gotong Royong }\end{array}$ & $\begin{array}{l}\text { Konten Paket } \\
\text { Pembelajran }\end{array}$ \\
\hline \multirow{6}{*}{ Tokoh Sema } & $\begin{array}{l}\text { 1) Serangga cerdas yang bekerja } \\
\text { dalam kelompok dengan } \\
\text { pembagian tugas menjadi: } \\
\text { semut tantara, pekerja, ratu, } \\
\text { jantan }\end{array}$ & $\begin{array}{l}\text { 1) Suka bekerja sama } \\
\text { dan berbagi tugas }\end{array}$ & $\begin{array}{l}\text { Buku Cerita: } \\
\text { "Mencontoh Sema" }\end{array}$ \\
\hline & $\begin{array}{l}\text { 2) Semut bekerja dan berbaris } \\
\text { dengan tertib }\end{array}$ & $\begin{array}{l}\text { 2) Tertib dalam } \\
\text { melakukan sesuatu }\end{array}$ & $\begin{array}{l}\text { "Lagu Karakter: Ayo } \\
\text { Kerja Bersama!" }\end{array}$ \\
\hline & $\begin{array}{l}\text { 3) Semut mau mengangkat } \\
\text { makanan berukuran } 50 \text { kali dari } \\
\text { berat tubuhnya }\end{array}$ & 3) Tekun bekerja keras & $\begin{array}{l}\text { Kalimat Inspiratif: Aku } \\
\text { suka bekerja sama dan } \\
\text { menolong orang lain }\end{array}$ \\
\hline & $\begin{array}{l}\text { 4) Semut punya kantong perut } \\
\text { yang dipakai untuk menyimpan } \\
\text { makanan dan diberikan pada } \\
\text { semut lain yang kelaparan }\end{array}$ & $\begin{array}{l}\text { 4) Peduli pada anggota } \\
\text { kelompok }\end{array}$ & $\begin{array}{l}\text { Kata fokus karakter: } \\
\text { kerja sama, tertib, kerja } \\
\text { keras, peduli, } \\
\text { komunikasi, } \\
\text { musyawarah }\end{array}$ \\
\hline & $\begin{array}{l}\text { 5) Semut memiliki antena yang } \\
\text { digunakan untuk saling } \\
\text { menyapa, berkomunikasi, } \\
\text { memberi informasi makanan } \\
\text { dan tanda bahaya }\end{array}$ & $\begin{array}{l}\text { 5) Saling berkomunikasi } \\
\text { dengan baik }\end{array}$ & \\
\hline & $\begin{array}{l}\text { 6) Semut berpindah-pindah rumah } \\
\text { untuk beradaptasi di lingkungan } \\
\text { sesuai kesepakatan bersama }\end{array}$ & $\begin{array}{l}\text { 6) Mau berdiskusi } \\
\text { (musyawarah) untuk } \\
\text { mengambil } \\
\text { keputusan }\end{array}$ & \\
\hline
\end{tabular}


Penelitian pengembangan menghasilkan produk paket pembelajaran yang terdiri dari: materi pembelajaran, media penunjang berupa: buku cerita, lagu karakter dan video pembelajaran, asesmen dan aktivitas keterlibatan orang tua. Paket Pembelajaran Tokoh Sema menjadi referensi dan panduan bagi pendidik, anak maupun orang tua dalam menanamkan nilai gotong royong yang sebelumnya jarang dibahas secara khusus dalam kegiatan pembelajaran. Paket pembelajaran tokoh Sema disajikan pada tabel 2.

Tokoh inspiratif Sema yang menjadi muatan paket pembelajaran dikembangkan dengan prinsip pembelajaran PAUD, yaitu: sederhana, menarik, memiliki contoh konkrit, memberi pengalaman nyata, serta melibatkan orang tua. Pengembangan paket pembelajaran sebaiknya memuat konten sederhana, instruksi yang jelas, memiliki lembar kerja penguatan yang dapat diamati, serta dapat dipraktikan sesuai karakteristik anak (Sawangsri, 2016). Hasil penelitian menunjukkan kesesuaian pengembangan konten paket pembelajaran tokoh inspiratif yang terdiri dari media pembelajaran berupa buku cerita bergambar, video lagu karakter dan video pembelajaran yang menarik dan konkrit. Berikut pembahasan dari masing-masing komponen paket pembelajaran.

\section{Materi Pembelajaran Tokoh Sema}

Bagian pertama paket pembelajaran ada materi tokoh inspiratif Sema yang digunakan sebagai panduan pendidik. Dalam proses pengembangan materi pembelajaran, diperlukan kreativitas pendidik untuk mendesain kegiatan maupun membuat kreasi dari bahan yang diberikan. Pendidik yang kreatif dalam mengembangkan materi pembelajaran dan aktivitas permainan mencegah anak merasa tertekan dan kehilangan keterampilan berpikir akibat tuntutan akademis (Seevak, 2020). Meski materi pembelajaran berperan penting dalam keberhasilan, namun tidak semua pendidik mampu menyusun materi yang berdasarkan karakteristik anak atau mengadopsi materi yang sudah ada sesuai kebutuhan (Rahamat et al., 2011). Oleh karena itu, keberadaan materi pembelajaran tokoh menjadi panduan yang menolong pendidik merancang pengembangan aktivitas bermuatan nilai karakter kebangsaan gotong royong. Hal ini juga ditemukan dalam penelitian, dimana semangat dan motivasi pendidik untuk mengembangkan materi karakter kebangsaan sesuai dengan keunikan dan program sekolah adalah prasyarat agar aktivitas penanaman karakter dapat berjalan secara berkesinambungan.

Materi Pembelajaran Tokoh Sema dijabarkan dalam bentuk narasi yang mencakup keenam aspek perkembangan anak. Aspek nilai agama dan moral dan sosial emosional dikenalkan melalui penjelasan mengenai sikap dan karakter serta praktik penerapan nilai gotong royong saat pembelajaran. Aspek kognitif distimulasi dengan adanya gambar dan penjelasan mengenai ciri tubuh dan cara hidup tokoh Sema yang merepresentasikan nilai gotong royong. Aspek perkembangan bahasa distimulasi melalui kegiatan bercerita dan pengenalan kosa kata baru mengenai kehidupan Tokoh Sema. Aspek motorik dikembangkan dengan adanya gerak dan lagu serta aktivitas senam fantasi Tokoh Sema. Aspek seni mendapat stimulasi melalui aktivitas bernyanyi, sajak serta membuat hasil karya seputar tokoh Sema. Materi pembelajaran Sema disajikan pada gambar 1.

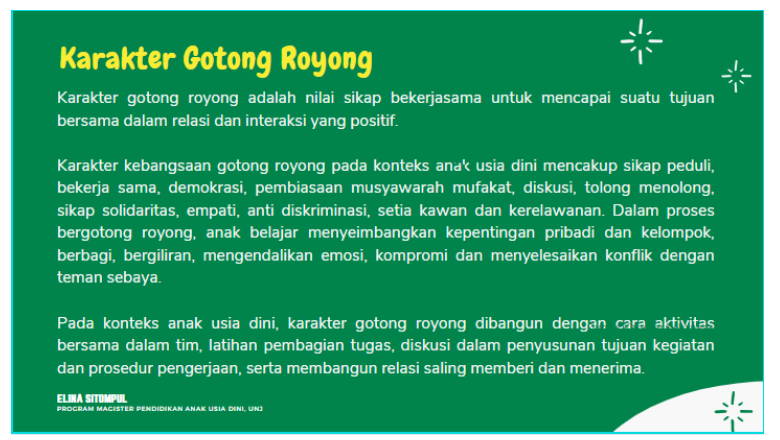

Halaman 1

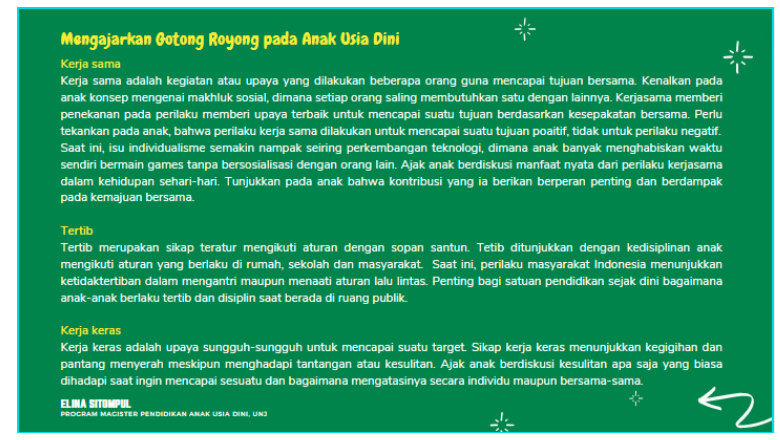

Halaman 2 


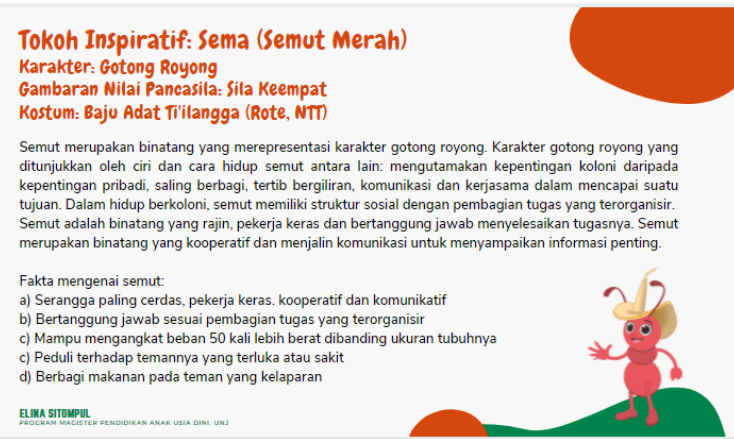

Halaman 3

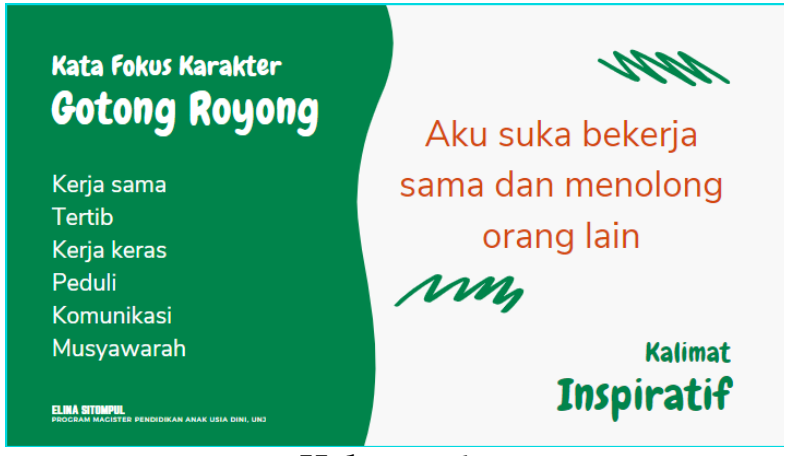

Halaman 4

\section{Gambar 1. Materi Pembelajaran Sema}

\section{Buku Cerita Tokoh Sema}

Selain mendesain materi pembelajaran, peneliti juga mengembangkan buku cerita berjudul "Mencontoh Sema". Buku cerita merupakan salah satu media pembelajaran yang efektif digunakan dalam pembelajaran anak usia dini (Ramírez et al., 2017). Kegiatan membaca buku cerita merupakan momentum berharga bagi orang dewasa untuk mengomunikasikan sesuatu dan menyampaikan pesan pada anak (Cárdenas et al., 2020). Melalui paket buku cerita, orang dewasa dapat mengenalkan nilai moral dan karakter pada anak usia dini (Murtafiah, Masrura, et al., 2018). Buku cerita menjadi sarana menerjemahkan nilai kebangsaan yang abstrak menjadi konkret melalui kisah, perilaku dan ciri tokoh. Oleh karena itu, peneliti mendesain buku cerita tokoh Sema yang bermuatan nilai karakter gotong royong untuk menyampaikan pesan dan memberi anak contoh keteladanan sikap karakter yang dapat ditarik relevansinya dalam kehidupan sehari-hari anak. Buku gambar yang mencontoh Sema dapat dilihat pada gambar 2.

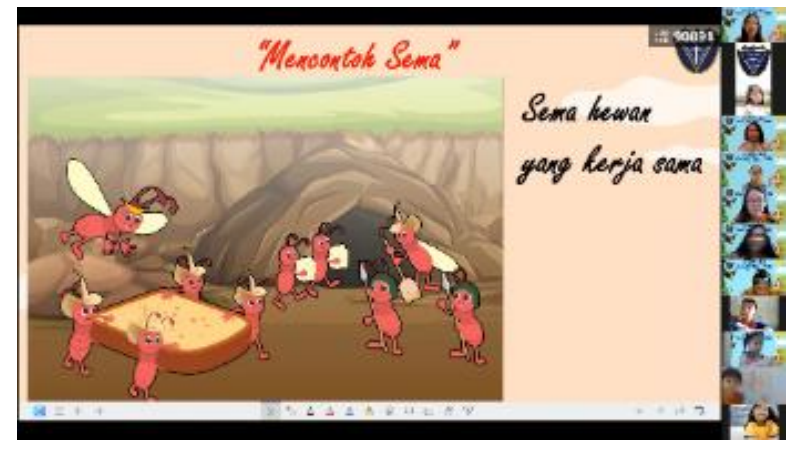

Halaman 1

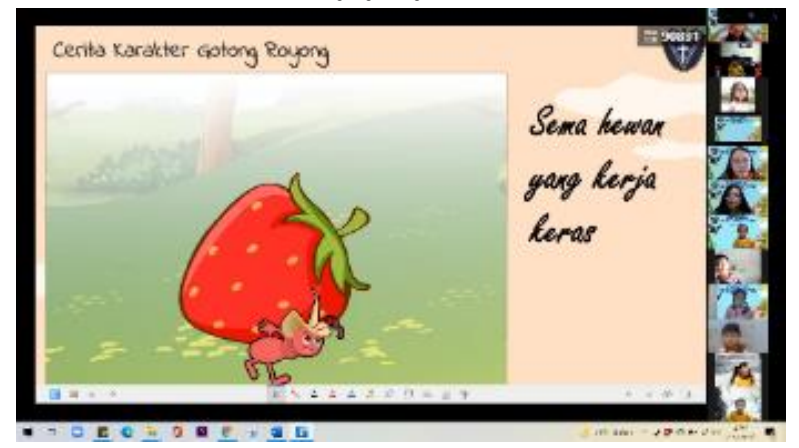

Halaman 3

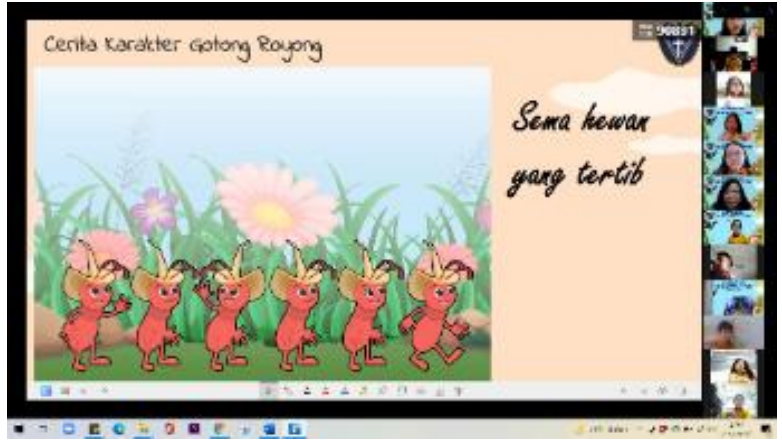

Halaman 2

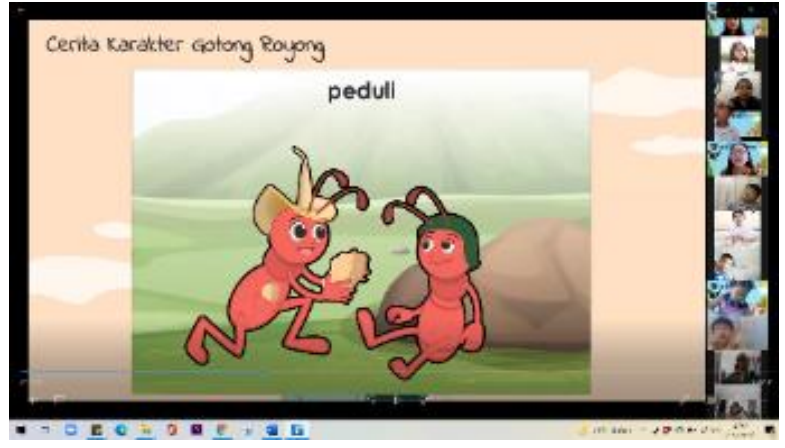

Halaman 4 


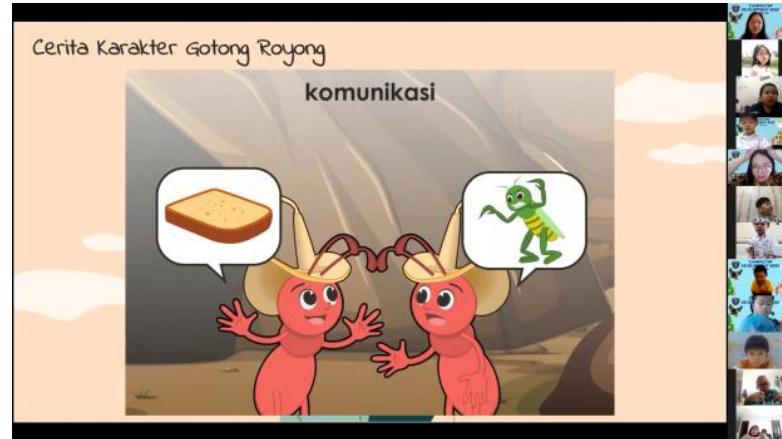

Halaman 5

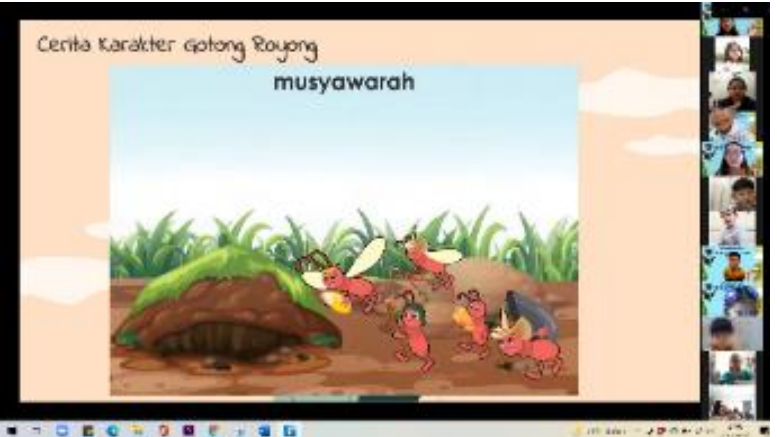

Halaman 6

Gambar 2. Buku Cerita "Mencontoh Sema"

\section{Gerak dan Lagu Karakter Gotong Royong}

Media kedua yang didesain peneliti adalah lagu bertemakan gotong royong dengan muatan tokoh Sema yang berjudul: Ayo Kerja Bersama. Gambar 3 adalah lirik lagu dan gambar video lagu Ayo Kerja sama.

\author{
Ayo Kerja Bersama \\ Lirik \& Musik: Elina Sitompul \\ Ayo kerja, ayo kerja, seperti semut \\ Ayo b'ri tenagamu kerja yang giat \\ Ayo kerja, ayo kerja, bersama-sama \\ Lakukan dengan tertib, \\ Bertanggung jawab \\ Dan saling peduli
}

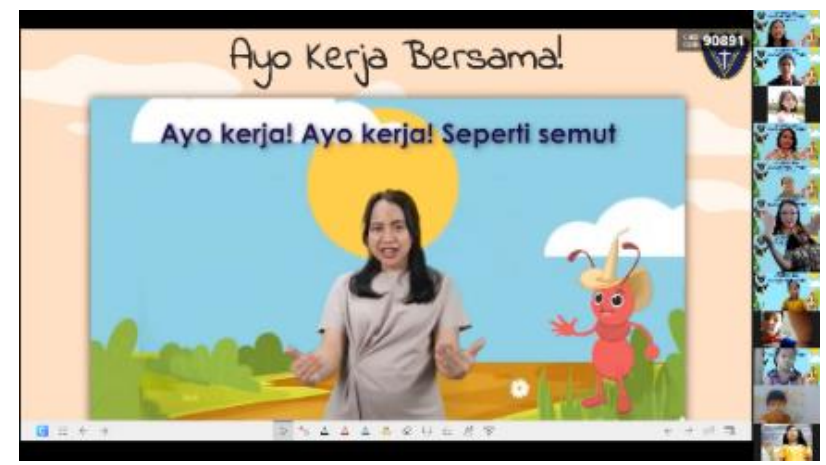

Gambar 3. Lirik lagu dan Foto Video Lagu Ayo Kerja Bersama (Klik pada gambar untuk menonton video)

Rangkaian proses implementasi menunjukkan lagu karakter yang diciptakan mudah diikuti anak dan pendidik, menarik, sederhana, diiringi musik yang riang serta mempunyai lirik bermakna yang bernilai kebaharuan. Lagu merupakan media yang dekat dan efektif dalam pembelajaran anak usia dini. Lagu anak usia dini memiliki karakteristik: menyenangkan, berisi pengulangan syair, pola bahasa mudah diikuti, memiliki ritme dan pengucapan sederhana, membawa atmosfer positif serta bermakna (Dzanic \& Pejic, 2016). Pada penelitian ini, peneliti menciptakan lagu yang disertai gerakan sebagai representasi tokoh Sema dengan lirik bermuatan karakter kebangsaan gotong royong. Pembuatan musik yang menyenangkan bagi anak prasekolah dapat mengaktifkan dan menstimulasi saraf yang terlibat dalam pembentukan regulasi emosional (Williams, 2018). Partisipasi anak dalam kegiatan bermusik mendorong pembentukan perilaku prososial, seperti: menolong, berbagi dan sikap kolaborasi (Ilari et al., 2020). Lagu karakter tokoh Sema dengan lirik bermuatan nilai gotong royong merupakan media pembentukan perilaku prososial dan memberi penguatan terhadap nilai-nilai yang dipelajari anak melalui aktivitas cerita bergambar.

\section{Video Pembelajaran Tokoh Sema}

Pengembangan buku cerita dan lagu karakter dilengkapi dengan video pembelajaran Sema. Video pembelajaran menjadi salah satu bentuk media yang efektif untuk digunakan, khususnya saat masa belajar dari rumah. Video pembelajaran menjadi alat pendidik untuk menyampaikan materi nilai karakter kebangsaan melalui tokoh Sema. Paket Pembelajaran Tokoh Sema disampaikan dalam dua rangkaian video yang masing-masing berdurasi 14 
menit. Pada bagian pembukaan video, peneliti menyampaikan melakukan tanya jawab mengenai Tokoh Sema. Pada bagian inti, dijabarkan mengenai materi nilai gotong royong yang direpresentasikan oleh Tokoh Sema. Pada bagian penutup, dilakukan tanya jawab mengenai contoh perilaku gotong royong serta relevansi penerapannya dalam kehidupan sehari-hari.

Penyampaian bahan ajar melalui media berbasis digital menyediakan pendidik kesempatan untuk memenuhi ragam kebutuhan anak dalam pembelajaran (Kusumadewi et al., 2021). Video dapat digunakan pendidik sebagai media pembelajaran karakter, guna memberi gambaran nilai karakter yang ingin ditanamkan pada anak usia dini melalui cara yang berkesan dan lebih kaya pengalaman (Fitria \& Juwita, 2018). Penggunaan video pembelajaran tidak hanya menarik bagi peserta didik, tetapi juga mendorong pendidik semakin reflektif, mendalami bahan ajar yang disampaikan serta memberi kesempatan saling berdiskusi dan bertukar bahan ajar yang mengutungkan rekan sejawat (Cherrington \& Loveridge, 2014). Temuan ini menguatkan hasil penelitian yang menunjukkan bahwa video pembelajaran tokoh Sema mampu menjadi sarana penanaman karakter kebangsaan dan memperkaya pengalaman belajar anak mengenai contoh-contoh nyata perilaku karakter kebangsaan, khususnya dalam kegiatan belajar dari rumah. Video pembelajaran gotong royong dapat dilihat pada gambar 4 .

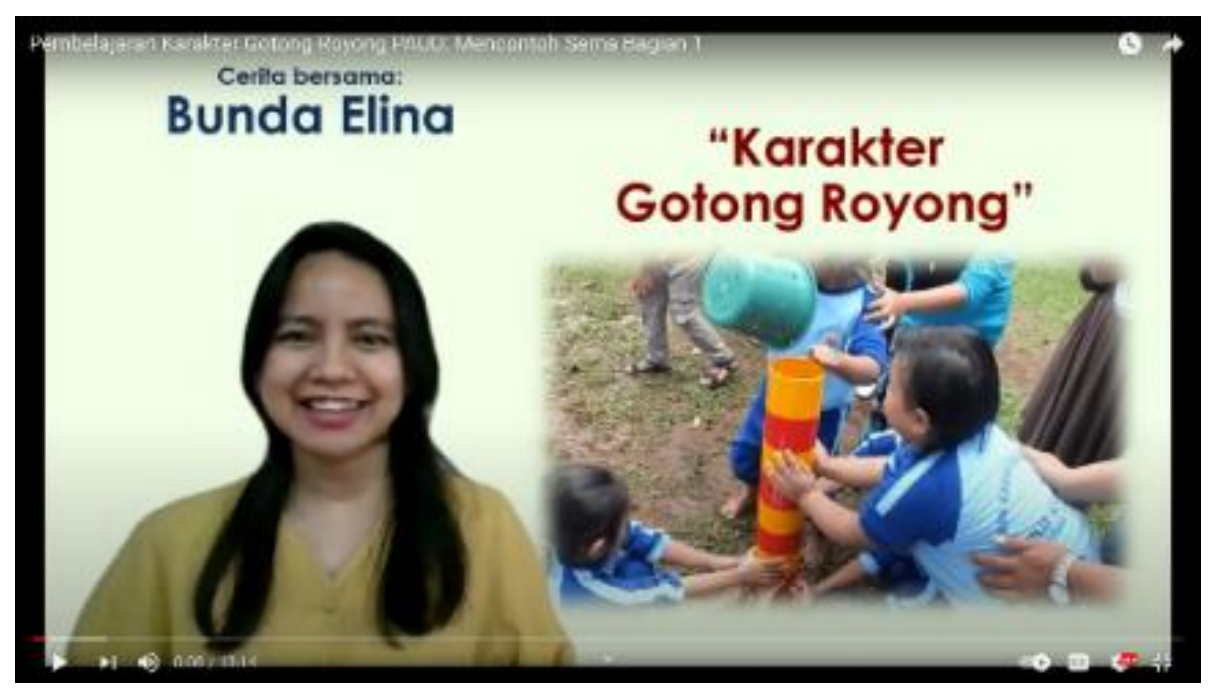

Gambar 4. Video Pembelajaran Gotong Royong (klik pada gambar untuk menonton video)

\section{Asesmen Karakter Kebangsaan}

Asesmen karakter pada peserta didik tidak dapat berdiri sendiri dan dilakukan untuk menemukan sejauh mana anak memanisfestasikan pemahaman tentang suatu karakter, berkomitmen untuk melakukan serta bertindak atas nilai karakter yang dipelajari (Lickona et al., 2011). Asesmen yang dikembangkan pada Paket Pembelajaran Tokoh Sema berupa ceklis perkembangan dimana indikatornya merupakan turunan dari Kompetensi Dasar Kurikulum 2013. Dari hasil penelitian direkomendasikan bahwa apabila paket pembelajaran digunakan mulai awal tahun pelajaran, maka pendidik dapat melalukan pemetaan KD dan mengintegrasikan penilaian karakter dalam pembelajaran harian sepanjang tahun pelajaran dengan lebih terprogram. Untuk melengkapi penilaian yang dilakukan guru, perlu adanya keterlibatan dan pertimbangan laporan orang tua selaku lingkungan terdekat yang berkontak langsung dengan anak (Li et al., 2019). Dengan adanya asesmen, pendidik mampu mengidentifikasi perkembangan dan kebutuhan anak, menganalisa ketercapaian tujuan pembelajaran serta mengumpulkan informasi untuk pengembangan program berikutnya (Buzzelli, 2018). Desain ceklis perkembangan karakter gotong rotong disajikan pada tabel 4. 
Tabel 4 Desain Ceklis Perkembangan Karakter Gotong Royong

\begin{tabular}{|c|c|c|c|c|c|}
\hline \multirow{2}{*}{ No. } & \multirow{2}{*}{ KD } & \multirow{2}{*}{ Indikator Karakter Gotong Royong } & \multicolumn{3}{|c|}{ Skala Penilaian } \\
\hline & & & BB $\mathbf{M B}$ & BSH & BSB \\
\hline & 3.5, & Anak berinisiatif untuk mencari pemecahan masalah & & & \\
\hline 1 & 4.5 & bersama & & & \\
\hline 2 & 2.11 & Anak mampu bekerja sama dalam kelompok & & & \\
\hline 3 & 2.10 & Anak menghargai karya orang lain & & & \\
\hline 4 & 2.12 & Anak berperan aktif mengerjakan tanggung jawab bersama & & & \\
\hline 5 & 2.7 & Anak mampu menerima perbedaan pendapat & & & \\
\hline 6 & 2.11 & $\begin{array}{l}\text { Anak berpendapat \& berekspresi dengan cara yang dapat } \\
\text { diterima }\end{array}$ & & & \\
\hline & & Anak mengenal istilah musyawarah untuk mencapai & & & \\
\hline 7 & 2.10 & kesepakatan bersama & & & \\
\hline 8 & 2.9 & Anak menunjukkan sikap kepedulian & & & \\
\hline
\end{tabular}

Keterangan:

BB: Belum Berkembang

BSH: Berkembang Sesuai Harapan
MB: Mulai Berkembang,

BSB: Berkembang Sangat Baik

\section{Strategi Implementasi Paket Pembelajaran dalam Proses Belajar dari Rumah (BdR)}

Implementasi paket pembelajaran dalam proses BdR menggunakan aplikasi belajar daring seperti zoom dan youtube. Implementasi paket pembelajaran tokoh inspiratif pada saat BdR menggunakan aplikasi WhatsApp, Zoom Meeting, dan Youtube. WhatsApp digunakan sebagai sarana komunikasi antara pendidik dan orang tua dalam proses pemberian dan pengumpulan tugas anak. Zoom Meeting dilakukan untuk kegiatan tatap muka secara daring serta pertemuan orang tua. Youtube digunakan penayangan video pembelajaran. Kelebihan menggunakan zoom meeting adalah adanya interaksi langsung antara anak, pendidik dan teman-teman, namun kekuranganya waktu tidak fleksibel dan konsentrasi anak cepat teralih. Kelebihan Youtube adalah mudah diakses orang tua dan anak secara fleksibel, namun kekurangannya tidak ada interaksi langsung dan jadwal belajar anak tidak menentu. Selain digunakan dalam proses BdR Paket Pembelajaran Tokoh Inspiratif dapat diimplementasikan dalam kegiatan belajar tatap muka di sekolah. Saat di sekolah, pendidik dapat merancang kegiatan saat pembukaan, inti, penutup atau program khusus sekolah.

Pada pembelajaran tatap muka terbatas, pendidik dapat mengatur alokasi waktu pengenalan tokoh inspiratif karakter kebangsaan pada saat kegiatan pembukaan (15 menit), kegiatan inti (30 menit) dan kegiatan penutup (15 menit). Ketika digunakan dalam proses belajar dari rumah, pendidik dapat mengalokasikan waktu 30 menit untuk pertemuan menggunakan zoom dan 8-10 menit untuk video pembelajaran menggunakan youtube. Pendidik juga memberi rekomendasi agar paket pembelajaran tokoh inspiratif digunakan mulai awal tahun ajaran agar dapat dilakukan pemetaan dan pengembangan program secara berkesinambungan serta dapat bermanfaat untuk seluruh anak. Adapun durasi ideal yang direkomendasikan untuk penggunaan paket pembelajaran adalah satu sub nilai dari masingmasing karakter dibahas 1 minggu dan direview setiap 3 minggu, sehingga 1 tokoh dibahas selama 2 bulan.

Proses belajar dari rumah bagi anak PAUD memiliki tantangan tersendiri, dimana sebuah penelitian menemukan $48,57 \%$ orang tua setuju mendukung pembelajaran anak dari rumah, 51,43\% tidak mendukung dan sisanya ragu-ragu (Munna \& Shaikh, 2020). Pembelajaran jarak jauh pada konteks anak usia dini menghadapi banyak tantangan dan kesulitan karena terbatasnya interaksi antara sesama anak dan pendidik yang menjadi modal pembelajaran nilai (Gasparini, 2021). Tantangan ini juga dihadapi selama penelitian dimana terdapat orang tua tidak memberi pendampingan belajar dari rumah secara optimal dikarenakan faktor pekerjaan dan kesibukan. 
Tantangan yang dihadapi dalam proses BdR diatasi dengan menjalin komunikasi efektif bersama orang tua. Anak-anak dengan orang tua yang proaktif dan melek teknologi menunjukkan hasil belajar dan keterlibatan yang lebih tinggi selama aktivitas pembelajaran (Kaynar et al., 2020). Pendidik perlu memiliki keterampilan khusus dalam berkomunikasi mengingat orang tua peserta didik memilki latar belakang, bentuk partisipasi dan kemampuan yang beragam (Parra et al., 2017). Pada penelitian ini, komunikasi umumnya dilakukan melalui WA, dimana pendidik memberikan deskripsi berupa tulisan dan juga penjelasan lisan melalui rekaman audio. Pendidik melakukan pendekatan dengan orang tua untuk pengembangan aktivitas di rumah. Adapun untuk alokasi waktu, durasi 30 menit untuk pertemuan menggunakan zoom dan 8-10 menit untuk video pembelajaran menggunakan youtube.

\section{Prosedur Penggunaan Paket Pembelajaran}

Metode yang digunakan adalah: bercerita, tanya jawab, diskusi dan praktik langsung. Dalam penanaman karakter anak, diskusi mengenai suatu nilai meningkatkan pemahaman anak mengenai suatu karakter, membangun empati, melatih anak menunjukkan beragam cara pemecahan masalah dan membuat perencanaan efektif dalam mengimplementasi suatu nilai dalam keseharian mereka (Wee \& Lee, 2020). Saat berada di rumah, orang tua dapat menceritakan kembali kisah tokoh inspiratif, melakukan tanya jawab, diskusi bersama nilai karakter kebangsaan, gerak dan lagu bersama serta melakukan aktivitas penguatan karakter kebangsaan bersama anak. Gambar 5 disajikan gambaran prosedur penggunakan Paket Pembelajaran Tokoh Sema.

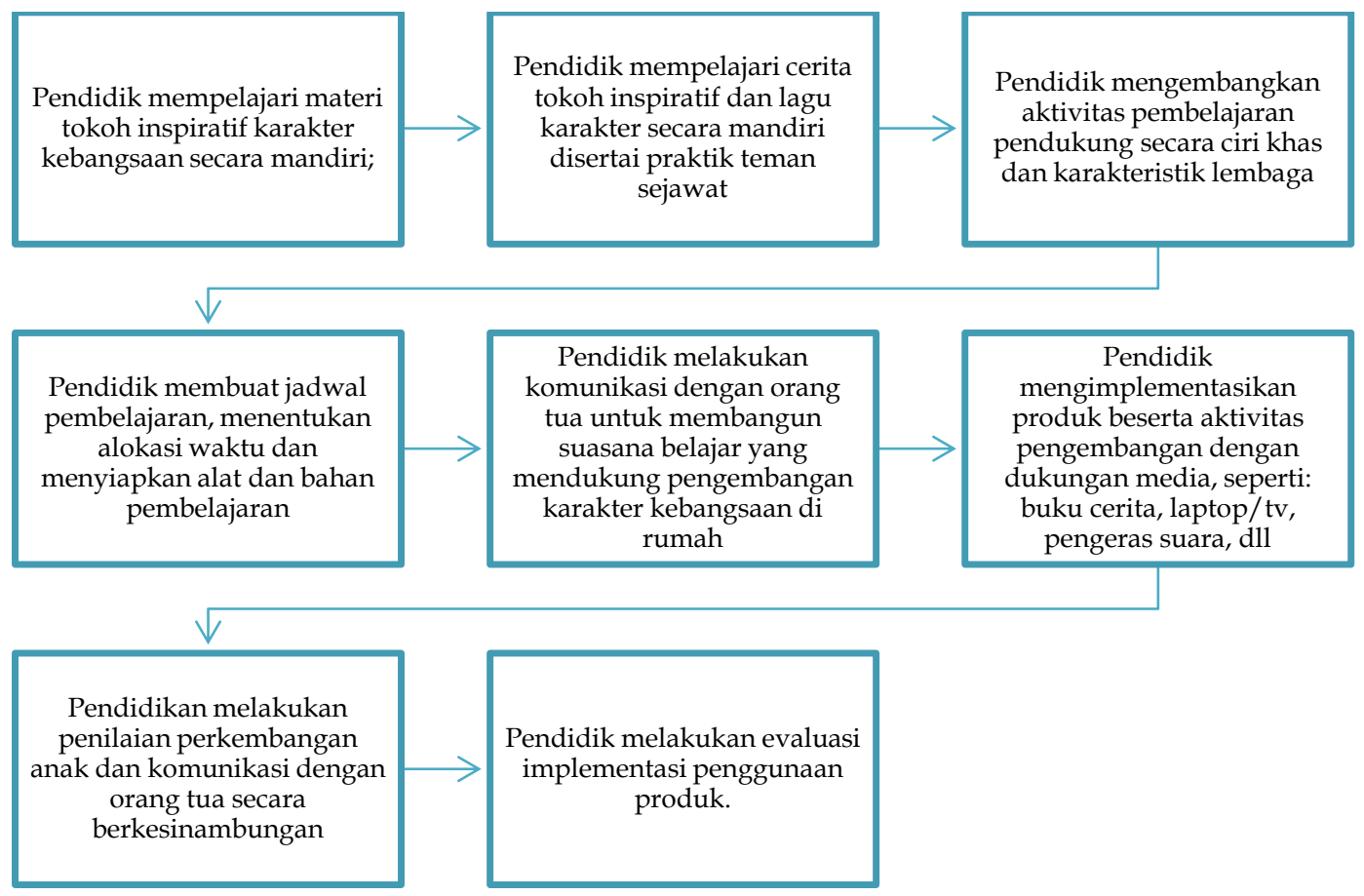

\section{Gambar 5. Prosedur Penggunaan Paket Pembelajaran Tokoh Sema}

Rangkaian proses penggunaan Paket Pembelajaran Tokoh Sema di satuan pendidikan memiliki rangkaian pola sebagai berikut: penyamaan persepsi oleh pendidik melalui kegiatan diskusi, pengembangan program sesuai ciri dan karakterisik satuan PAUD, pendidik melakukan praktik implementasi produk secara mandiri maupun peer teaching, sekolah membangun komunikasi efektif dengan orang tua mengenai nilai karakter, melakukan proses implementasi dan asesmen dan pemberian umpan balik dari orang tua maupun anak. Penelitian sebelumnya menemukan bahwa membangun kekuatan karakter pada pendidik 
PAUD membutuhkan pelatihan atau program khusus, serta ditanamkan melalui praktik sehari-hari melalui kegiatan yang berkesinambungan (Vuorinen et al., 2021). Penyamaan persepsi idealnya dilakukan oleh peneliti dan seluruh pemangku kepentingan (minimal pendidik dan kepala sekolah). Proses pengembangan program disesuaikan dengan karakterisik sekolah dan anak. Praktik mandiri dan teman sejawat dilakukan sebagai tahap persiapan dalam kurun waktu 1-7 hari. Komunikasi dengan orang tua yang menjadi rekan sekolah dalam menanamkan nilai karakter dalam diri anak. Pemberian umpan balik diberikan oleh orang tua dan sesama pendidik guna perbaikan dan pengembangan kegiatan kedepannya.

\section{Karakter Gotong Royong Anak Usia 4-6 Tahun}

Selama proses implementasi, pendidik melakukan pengamatan perkembangan karakter gotong royong anak kelompok A dan B. Beberapa indikator yang muncul dijabarkan melalui tabel 5 dan 6 .

Tabel 5. Rekapitulasi Ceklis Perkembangan Gotong Royong Kel. A

\begin{tabular}{lcccc}
\hline Indikator Perkembagan & \multicolumn{4}{c}{ Inisial Nama Anak } \\
Karakter Gotong Royong & ZA & RE & SA & GR \\
\hline Anak menunjukkan sikap tertib saat mengantri (2.6) & BSH & MB & BSH & BSH \\
Anak mampu menyesuaikan diri dalam bekerja sama (2.11) & BSH & MB & BSH & BSH \\
Anak menunjukkan sikap mau bekerja sama di rumah (2.12) & BSH & MB & BSH & BSH \\
Anak mau mendengarkan orang lain ketika berbicara (2.7) & BSH & MB & BSH & BSH \\
Anak menunjukkan sikap peduli dengan menolong orang lain (2.9) & BSH & MB & BSH & BSH \\
Anak membedakan perilaku baik berdasarkan Gambar (3.2, 4.2) & BSH & MB & BSH & BSH \\
\hline
\end{tabular}

Tabel 6. Rekapitulasi Ceklis Perkembangan Gotong Royong Kel. B

\begin{tabular}{|c|c|c|c|c|c|}
\hline \multirow{2}{*}{$\begin{array}{l}\text { Indikator Perkembagan } \\
\text { Karakter Gotong Royong }\end{array}$} & \multicolumn{5}{|c|}{ Inisial Nama Anak } \\
\hline & AL & CI & DA & JA & NA \\
\hline Anak menunjukkan sikap tertib saat mengantri (2.6) & BSB & BSB & BSH & BSH & BSB \\
\hline Anak mampu menyesuaikan diri dalam bekerja sama (2.11) & BSB & BSB & $\mathrm{BSH}$ & $\mathrm{BSH}$ & $\mathrm{BSH}$ \\
\hline Anak menunjukkan sikap mau bekerja sama di rumah (2.12) & BSB & BSB & $\mathrm{BSH}$ & $\mathrm{BSH}$ & BSB \\
\hline Anak mau mendengarkan orang lain ketika berbicara (2.7) & $\mathrm{BSH}$ & $\mathrm{BSH}$ & $\mathrm{BSH}$ & BSH & $\mathrm{BSH}$ \\
\hline $\begin{array}{l}\text { Anak menunjukkan sikap peduli dengan menolong orang lain } \\
\text { (2.9) }\end{array}$ & BSB & BSB & $\mathrm{BSH}$ & BSH & BSH \\
\hline Anak membedakan perilaku baik berdasarkan Gambar $(3.2,4.2)$ & BSB & BSB & $\mathrm{BSH}$ & $\mathrm{BSH}$ & $\mathrm{BSH}$ \\
\hline
\end{tabular}

Berdasarkan data pada tabel 5 dan 6 diperoleh dari 9 peserta didik, 3 anak memperoleh kriteria Berkembang Sangat Baik (BSB), 4 anak memperoleh kriteria Berkembang Sesuai Harapan (BSH), sedangkan 1 anak menunjukkan Mulai Berkembang untuk indikator karakter gotong royong. Hasil penilaian ini menunjukkan tanda-tanda terbentuknya karakter gotong royong pada anak usia 4-6 tahun. Adapun indikator gotong royong ditunjukkan anak antara lain: 1) Anak mampu tertib mengantri; 2) Anak mampu membuat aturan kelompok bersama; 3) Anak mampu menaati aturan kelompok pada saat mengerjakan tugas; 4) Anak mampu berbicara bergantian; 5) Anak menunjukkan sikap peduli melalui cerita tolong menolong. Beberapa indikator perkembangan yang muncul menunjukkan keberhasilan proses penanaman karakter kebangsaan menggunakan paket pembelajaran tokoh inspiratif. Ciri perilaku gotong royong anak usia dini diantaranya: memiliki sikap peduli, menghargai kesepakatan bersama, membiasakan musyawarah, mau berdiskusi, menunjukkan kesetiakawanan dan tolong menolong (Direktorat Pembinaan Pendidikan Anak Usia Dini, 2019). 


\section{SIMPULAN}

Paket pembelajaran Tokoh Sema didesain sebagai sarana penanaman nilai karakter kebangsaan gotong royong anak usia 4-6 tahun. Paket pembelajaran terdiri dari beberapa komponen, yaitu: materi pembelajaran, media berupa buku cerita, lagu karakter, video pembelajaran, serta asesmen karakter kebangsaan dan aktivitas keterlibatan orang tua. Rangkaian proses penggunaan paket pembelajaran tokoh inspiratif karakter kebangsaan di satuan pendidikan mengikuti pola penyamaan persepsi pendidik, pengembangan program sesuai ciri dan karakteristik satuan PAUD, praktik mengajar mandiri, membangun komunikasi efektif dengan orang tua mengenai nilai karakter, dan proses implementasi dan asesmen, serta 6) pemberian umpan balik oleh peserta didik dan orang tua.

\section{UCAPAN TERIMA KASIH}

Peneliti mengucapkan terima kasih kepada Tuhan Yesus atas pertolongan sehigga mampu menyelesaikan penelitian dengan baik. Terima kasih kepada kedua dosen pembimbing: Dr. Nurbiana Dhieni, M.Psi. dan Dr. Hapidin, M.Pd. yang telah memberi arahan selama proses penelitian. Peneliti juga mengucapkan terima kasih kepada kedua orang tua dan keluarga yang senantiasa memberi dukungan doa. Akhir kata peneliti berterima kasih kepada TK Methodist Jakarta atas kerja sama yang diberikan selama proses penelitian.

\section{DAFTAR PUSTAKA}

Akbar, D., Ibrahim, N., \& Sukardjo, M. (2019). Pengembangan Paket Pembelajaran IPS Multi Media dalam Pembelajaran IPS Kelas VIII di MTSN 24 Jakarta. Jurnal Ilmiah Wahana Pendidikan, 5 No. 1.

Al-Delaimy, A. K., Al-Mekhlafi, H. M., Lim, Y. A. L., Nasr, N. A., Sady, H., Atroosh, W. M., \& Mahmud, R. (2014). Developing and evaluating health education learning package (HELP) to control soil-transmitted helminth infections among Orang Asli children in Malaysia. Parasites and Vectors, 7(1), 1-18. https://doi.org/10.1186/1756-3305-7-416

Blake H, Bermingham F, Johnson G, \& Tabner A. (2020). Mitigating the psychological impact of covid-19 on healthcare workers: A digital learning package. International Journal of Environmental Research and Public Health, núm 17. Recuperado el 16 de Agosto del 2020. International Journal of Environmental Research and Public Health, 17(2997), 115. https:// doi.org/10.3390/ijerph17092997

Buzzelli, C. A. (2018). The moral dimensions of assessment in early childhood education. SAGE: Contemporary Issues in Early Childhood, 19(2), 154-166. https://doi.org/10.1177/1463949118778021

Cárdenas, K., Moreno-Núñez, A., \& Miranda-Zapata, E. (2020). Shared Book-Reading in Early Childhood Education: Teachers' Mediation in Children's Communicative Development. Frontiers in Psychology, 11(September). https://doi.org/10.3389/fpsyg.2020.02030

Cherrington, S., \& Loveridge, J. (2014). Using video to promote early childhood teachers' thinking and reflection. Teaching and Teacher Education, 41, 42-51. https://doi.org/10.1016/j.tate.2014.03.004

Choe, J. (2012). Secret Lives of Ants. In Science Books (3rd ed., Vol. 50, Issue 01). The John Hopkins University Press. https:// doi.org/10.5860/CHOICE.50-0281

Direktorat Pembinaan Pendidikan Anak Usia Dini. (2019). Panduan Praktis Penguatan Karakter Pada Pendidikan Anak Usia Dini. Kementerian Pendidikan dan Kebudayaan.

Djufri, M., \& Suardi. (2012). Pengembangan Paket Pembelajaran Berbasis Kewirausahaan: Suatu Inovasi Pembelajaran di Taman Kanak-Kanak. Jurnal Profesi Kependidikan, $1(1), 32$. 
Dzanic, N. D., \& Pejic, A. (2016). The Effect of Using Songs On Young Learners and Their Motivation for Learning English. NETSOL: New Trends in Social and Liberal Sciences, 1(2), 40-54. https:// doi.org/10.24819/netsol2016.8

Effendi, T. N. (2016). Budaya Gotong Royong Masyarakat Dalam Perubahan Sosial Saat Ini. Jurnal Pemikiran Sosiologi, 2(1), 1. https:// doi.org/10.22146/jps.v2i1.23403

Feldman, J., \& Karapetkova, H. (2010). Insect's Body. In The Lancet (Vol. 281, Issue 7295). Rourke Publishing LLC. https:/ / doi.org/10.1016/S0140-6736(63)91942-1

Fitria, Y., \& Juwita, J. (2018). Utilization of Video Blogs (Vlogs) in Character Learning in Early Childhood. Jurnal Obsesi: Jurnal Pendidikan Anak Usia Dini, 2(2), 211. https://doi.org/10.31004/obsesi.v2i2.87

Gasparini, S. (2021). Collaborative storytelling in distance education: a preliminary research with preschool children. Open Journal per La Formazione in Rete, 21(ISSN 1825-7321), 219-234.

Gordon, D. M. (2010). Ant Encounters: Interaction, Network and Colony Behavior. Princeton University Press. https:// doi.org/10.1515/9781400835447

Ilari, B., Helfter, S., \& Huynh, T. (2020). Associations Between Musical Participation and Young Children's Prosocial Behaviors. SAGE: Journal of Research in Music Education, 67(4), 399-412. https:// doi.org/10.1177/0022429419878169

Isfihani, I. (2017). Pembentukan Karakter Bangsa Melalui Paradigma Pendidikan. Al-Riwayah: Jurnal Kependidikan, 9(2), 375-406. https:// doi.org/10.32489/al-riwayah.146

Kaynar, N., Sadik, O., \& Boichuk, E. (2020). Technology in Early Childhood Education: Electronic Books for Improving Students' Literacy Skills. TechTrends, 64(6), 911-921. https://doi.org/10.1007/s11528-020-00520-5

Kostelnik, M. J., Gregory, K. M., Soderman, A. K., \& Whiren, A. P. (2012). Guiding Children's Social Development and Learning. In M. Kerr (Ed.), Cengage Learning (7th ed.). Wadsworth Cengage Learning.

Kusumadewi, R. F., Islam, U., \& Agung, S. (2021). Developing electronic teaching materials through comic mathematics media to increase student learning independence during the Covid-19 pandemic in Indonesia. İlköğretim Online, 20(1), 708-716. https:// doi.org/10.17051/ilkonline.2021.01.61

Lach, L., Parr, C. L., \& Abbott, K. L. (2010). Ant Ecology. In British Library Cataloguing. Oxford University Press. https:/ / doi.org/10.1093/acprof:oso/9780199544639.003.0016

Li, L., Fan, J., \& Jin, Z. (2019). Comparing multimethod assessment of approaches to learning among preschool children: Direct measure, teacher report, and parent report. WILEY: Psychology in the Schools, 56(8), 1271-1286. https:/ / doi.org/10.1002/pits.22274

Lickona, T., Schaps, E., \& Lewis, C. (2011). Eleven Principles of Effective Character Education. CEP: Character Education Partnership, 2007, 2-7.

Munna, A. S., \& Shaikh, M. S. I. (2020). Working from Home vs Learning from Home: A Critical Investigation and Analysis during the COVID-19. Asian Journal of Education and Social Studies, 12(3), 23-29. https://doi.org/10.9734/ajess/2020/v12i330312

Murtafiah, Inaya Masrura, S., Indrawati, N., \& Arsyad, N. (2018). The Practically and Effectiveness of Learning Package That Based on Metacognitive To Build the Students Character. International Journal of Education and Research, 6(4), 339-348. www.ijern.com

Murtafiah, Masrura, S. I., Indrawati, N., Arsyad, N., \& Awi. (2018). The Development of Learning Package Based on Metacognitive Strategies to Build the Students Character. Journal of Physics: Conference Series, 1028(1). https://doi.org/10.1088/1742$\underline{6596 / 1028 / 1 / 012127}$

Ocampo-Gooding, S. (2018). The Sheela-na-gig: An Inspirational Figure for Contemporary Irish Art. Concordia University Montreal, August.

Parra, J., Gomariz, M. ángeles, Hernández-Prados, M. ángeles, \& García-Sanz, M. P. (2017). Family involvement in early childhood education. RELIEVE - Journal of Educational 
DOI: 10.31004/obsesi.v6i4.1674

Research, Assessment and Evaluation, 23(1), 1-24.
https://doi.org/10.7203/relieve.23.1.9258

Rahamat, R., Language, E., Centre, T., \& Shah, P. M. (2011). Learners ' Evaluation of an eLearning Material (Issue March 2015). Universiti Kebangsaan Malaysia.

Ramírez, E., Clemente, M., Recamán, A., Martín-Domínguez, J., \& Rodríguez, I. (2017). Planning and Doing in Professional Teaching Practice. A Study with Early Childhood Education Teachers Working with ICT (3-6 years). Early Childhood Education Journal, 45(5), 713-725. https:// doi.org/10.1007/s10643-016-0806-x

Rich, D. (2008). MegaSkills; Building Our Children's Character and Achievement for school and Life. 378.

Santrock, J. W. (2017). Life Span Develompent (16th ed.). McGraw-Hill Higher Education.

Sawangsri, B. (2016). Learning Package by Means of the Inductive Teaching with Group Process. Universal Journal of Educational Research, 4(8), 1924-1929. https://doi.org/10.13189/ujer.2016.040824

Searle, G. D., \& Hanrahan, S. J. (2011). Leading to inspire others: Charismatic influence or hard work? Leadership and Organization Development Journal, 32(7), 736-754. https://doi.org/10.1108/01437731111170021

Seevak, M. (2020). Beautiful Stuff Treasure Boxes: Leveling the playing field. Childhood Education, 96(2), 68-71. https:// doi.org/10.1080/00094056.2020.1733908

Shubert, J., Wray-Lake, L., Syvertsen, A. K., \& Metzger, A. (2019). Examining Character Structure and Function Across Childhood and Adolescence. Child Development, 90(4), e505-e524. https://doi.org/10.1111/cdev.13035

Trimuliana, I., Dhieni, N., \& Hapidin, H. (2019). Perilaku Religius Anak Usia 5-6 Tahun pada PAUD Model Karakter. Jurnal Obsesi : Jurnal Pendidikan Anak Usia Dini, 3(2), 570. https://doi.org/10.31004/obsesi.v3i2.251

Unayah, N. (2017). Gotong Royong Sebagai Modal Sosial Dalam Penanganan Kemiskinan. Sosio Informa, 3(1), 49-58. https:// doi.org/10.33007/inf.v3i1.613

Vuorinen, K., Pessi, A. B., \& Uusitalo, L. (2021). Nourishing Compassion in Finnish Kindergarten Head Teachers: How Character Strength Training Influences Teachers' Other-Oriented Behavior. Springer: Early Childhood Education Journal, 49(2), 163-176. https://doi.org/10.1007/s10643-020-01058-0

Wee, S. J., \& Lee, Y. (2020). Writing letters to characters in bullying-themed stories: An approach to educating about bullying in early childhood. Australasian Journal of Early Childhood, 45(3), 266-279. https://doi.org/10.1177/1836939120936002

Williams, K. E. (2018). Moving to the Beat: Using Music, Rhythm, and Movement to Enhance Self-Regulation in Early Childhood Classrooms. International Journal of Early Childhood, 50(1), 85-100. https://doi.org/10.1007/s13158-018-0215-y 